\title{
MANAGING BLOOD DONORSHIP: THE EFFECTOF MOTIVATION ON DONOR SATISFACTION AND LOYALTY
}

\author{
JOLANTA ŽEMGULIENE $\dot{1}^{1}$
}

Vilnius University (Lithuania)

\begin{abstract}
Increasing demand on blood supply and attempts of blood collecting agencies in recruiting and retaining blood donors require deeper knowledge of existing factors driving donor behaviour. This research address the need to explore the relationship of factors driving donor behaviour - motivation, satisfaction and loyalty. The objective of this study is to explore the conceptual model representing the effect of donor motivation on satisfaction, attitudinal loyalty and behavioural loyalty in the specific context of social marketing impact. Model, based on structural equation modeling technique was developed using the data of donor population of the nationwide blood collecting agency. Study empirically confirmed the causal positive effect of donor motivation on attitudinal loyalty, behavioural loyalty and relationship satisfaction. Study also revealed the main motives for donation relevant to the surveyed donor population. The power of motivation towards donor satisfaction and loyalty have increased during the period of five years due to the positive moderating influence of social marketing (Non-remunerated donorship promotion program).

KEYWORDS: donor motivation, donor relationship satisfaction, donor attitudinal loyalty, donor behavioural loyalty,
\end{abstract}

JEL CLASSIFICATION: M380.

\section{Introduction}

Service management researchers explore antecedents of desirable customer behaviour. The link of perceived customer satisfaction, loyalty and purchase intentions has become a focus of interest due to its effectiveness and implication for theory and firm's performance (Gupta, Zeithaml, 2006). Positive association between customer satisfaction and loyalty has been comprehensively explored in commercial settings (Anderson et al., 1994; Anderson, Sullivan, 1993; Gronholdt et al., 2000; Homburg, Giering, 2001; Oliver, 1999; Seiders et al., 2005). However, some limitations exist suggesting the satisfaction - loyalty association in the non-profit context (Arnett, et al., 2003). Donation intentions and behaviour in the health care blood collection settings is driven by the specific blood donor attitudes and intentions that affect his behaviour. Blood donor loyalty to blood collecting agency refers to repeated donations and dispositional attitude towards donation behaviour. Pursuit of the donor satisfaction - loyalty antecedents is considered addressing the increasing demand on blood supply and challenging attempts of blood collecting agencies worldwide in recruiting and retaining blood donors. Deeper knowledge about the existing factors driving donor loyalty and donation behaviour would be helpful for non-profit managers in their efforts to implement effective donor recruitment and retention strategies. As Thaler and Helmig (Thaler, Helmig, 2013) have reported, behavioural intentions could be influenced by the social marketing techniques. Exploring the antecedents of customer

1 Jolanta Žemgulienè - associate professor, doctor at Faculty of Economics, Department of Business, Vilnius University. Scientific interests: management problems in organizations, customers loyalty

E-mail: jolanta.zemguliene@ef.vu.lt 
loyalty behaviour, this study covers the problem of development and control of customer loyalty behaviour in the non-commercial settings.

Previous research focused on donor motivation as antecedent of blood donation behaviour and intentions (Sojka, Sojka, 2008; Bednall, Bove, 2011; Bednall, et al., 2013). Authors also provided results exploring the effects of organizational identification and identity salience on the donation behaviour (Boenigk, Helmig, 2013). However, it is supposed to be lack of conceptual and empirical research exploring the causal direction and impact of donor motivation on satisfaction, loyalty and donation behaviour.

This article addresses these limitations by investigating conceptual model representing the antecedents of donor behaviour. The aim of this study is to explore the conceptual model representing the relationship of blood donor motivation on donor satisfaction, attitudinal loyalty and behavioral loyalty in the specific context of social marketing impact.

The study provides empirical evidence on the overall effect of social marketing program on donor motivation and donor behaviour.

The proposed conceptual framework was tested on the donor population of the nationwide blood collecting agency. Model, based on structural equation modeling method was developed and tested for model stability. Sample data on the same donor population were collected in two sessions (December 2008 and December 2013) in order to verify alteration on the relationships of donor motivation, donor satisfaction and loyalty. The changes in donor motivation and behaviour have been expected due to the effect of the means of social marketing (Non-remunerated donorship promotion program), implemented during that period. The article begins with a conceptual framework and then unfolds as empirical study in which the results of two series of empirical study have been compared on the same donor population. The article concludes with a discussion of implications and research limitations.

\section{Conceptual Framework and Hypotheses}

The conceptual framework represented four simplifying components - donor motivation, satisfaction, attitudinal loyalty, behavioural loyalty.

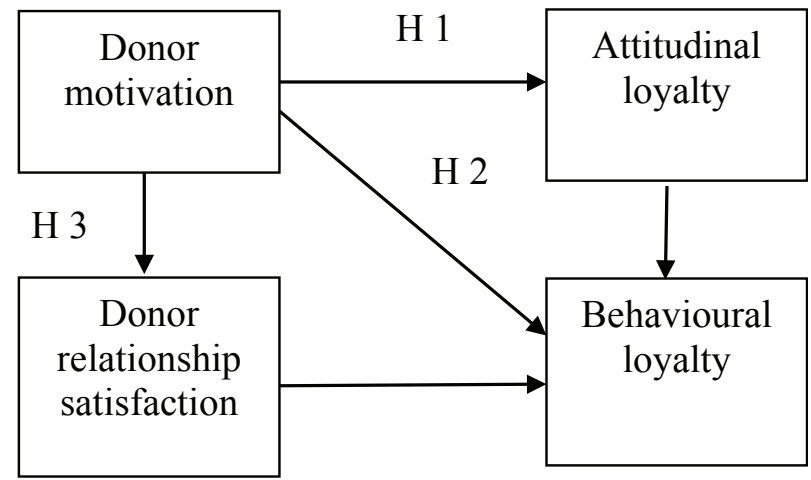

Figure 1. Conceptual model of donor motivation, satisfaction and loyalty

The augmented satisfaction - loyalty relationship included motivation, identified by the previous studies as the most important driver of donation behaviour (Sojka, Sojka, 2008; Bednall, Bove, 2011; Bednall et al., 2013). Some authors defined that customer satisfaction - loyalty association was sensitive to the customer characteristics and industry conditions (Anderson, Sullivan, 1993; Anderson, 1994; Bryant, Cha, 1996; Gronholdt et al., 2000; Mittal, Kamakura, 2001). Customer perceptions regarding the experience during the consumption of service is conjectured to be an attitudinal measure. As the industry context is relevant to the customer mindset, therefore it is significant for the customer behaviour. Consumption is goal - directed consumer behaviour, based on the ability to satisfy unfulfilled needs. Consumption could be caused by and result 
in value not associated to the money value exchange - the prosocial motivation, perceived need for social responsibility, general altruism, etc. Consumer satisfaction is defined as degree of pleasure in fulfilment of the desired need during the consumption. Therefore, there are needs which are satisfied by the products of no market value or value in exchange, utility for the customer could be derived from various charity forms.

Motives for giving in the non-profit industry are related to the needs, sufficiently driving person to donate. This research tested the hypothesized relationships of structural model in which the latent variable of donor motivation was not directionally influenced by other variables. Other variables in the model - donor satisfaction, donor loyalty, donations - were directionally influenced by donor motivation variable.

\subsection{Effects of donor motivation on donor loyalty}

The cognitive motivation theory proposes the motivation concepts based on perceived equity, need achievement, expectation and values (Van Raaij, Wandwossen, 1978). Need achievement concept explores the need as a determinant of consumer behavior. Consumer behaviour considering certain outcomes or consequences is based on choices, influenced by utility needs. Sheth (1976) has stated, that needs arose from functional, aesthetic, emotional, social, situational, curiosity motives. Motives to become a blood donor is determined by the cognitive association between accomplishment of individual personal blood donating act and the expectation that this donating act contributes to the satisfaction of a motivational need. In the field of health care and in the case of blood transfusion donating motives have been deeply studied. Researchers explored various self-reported motives for donating blood: influence from a friend, request via media, general altruism, social responsibility (Sojka, Sojka, 2008), convenience, pro-social motivation, personal values, collection agency reputation, perceived need for donation, and marketing communication values (Bednall, Bove, 2011; Bednall et al., 2013), feelings of empathy or altruism, self-benefit and external reasons (Karacan et al., 2013), general norm based altruism (Pennings, 2005; Otto, Bolle, 2011).

Motivation is directly linked to loyalty. This assumption has been in line with the theory of planned behaviour (Ajzen, 1991), which has explained relationship between behavioural, normative and control beliefs, attitude toward behaviour, subjective norm, perceived behavioural control and actual behaviour. Loyalty had behavioural and attitudinal parameters (Dick, Basu, 1994; Venkatesh et al., 2003), it has been defined as repeat purchase behaviour from the behavioural perspective and also has signified cognitive and emotional attachment from the attitudinal perspective. It could be generalized that motives are antecedents of beliefs, attitudinal loyalty refers to attitude toward behaviour and behavioural intentions. Some evidence exploring the antecedents of blood donation behaviour in the framework of the theory of planned behaviour has been provided in the literature. Bednall et al. (2013) has provided results of meta-analysis of the antecedents of blood donation behaviour and blood donation intentions, reporting medium positive association between the intentions to donate, perceived behavioural control, attitude toward donation, self-efficacy, donor's role identity. Repeated blood donation behavior is of critical importance in blood donation activity due to the role of repeated donorship for the safety of blood supply and recruitment of the sufficient number of donors. We predict that causal direction dominates in the direct link from motivation to loyalty; however, the causal direction has not been tested yet. Thus, two hypotheses are supported by this discussion, pertaining to the underexplored relationships of the donor motivation - satisfaction - loyalty framework:

Hypothesis 1: Donor motivation is causally and positively linked to attitudinal loyalty in non-profit blood donor settings.

Hypothesis 2: Donor motivation is causally and positively linked to behavioural loyalty in non-profit blood donor settings.

\subsection{Effects of donor motivation on donor satisfaction}

Satisfactory relationship is a critical factor for development of altruistic motivation of blood donors and long term nature of donor relationship to blood collecting agency. Customer satisfaction concept has been 
based on the expectancy - confirmation and disconfirmation paradigm (Anderson, 1994; Yi, 1991). From this point of view, relationship satisfaction has been in a non-profit context a positive affective state resulting from a perceived customer's experience of the relationship contingent upon expectations. This transaction specific satisfaction has led to cumulative satisfaction, as an overall satisfaction experience has originated from many discrete relationship acts, were being generated in a particular activity over a duration of time (Oliver, 1999; Fornell et al., 1996). With regard to blood donating activity, cumulative satisfaction is sensitive to the achievement of donor's positive affective state during the single donating act. Deeper analysis of motivations not donate have suggested, that motivation not to donate originated from the negative experience during the donating transaction (Bednall, Bove, 2011). Therefore, transaction based relationship satisfaction can be seen as appropriate measure used to oversee outcomes of blood collection activity. For the majority of blood collecting agencies, the pursuit of donor relationship satisfaction is driven by a donor motivating efforts. The causal direction of the relationship between donor motivation and donor relationship satisfaction has not been explored yet. Increased customer involvement and motivation as a factor that enhance the likelihood of the customer post-consumption reaction has been tested in the commercial settings. Babin et al. (1994) have confirmed, that "consumers' satisfaction reaction is not invariant to changes in consumer's processing motivation". Satisfaction reaction depends on the significance of the consumption outcomes and the cognitive efforts in deriving these outcomes. Based on the theoretical arguments concerning the motivation - satisfaction association, positive association has been generalized to this study. We have predicted that higher donor motivation led to greater donor relationship satisfaction. Following hypothesis proposed:

Hypothesis 3: Donor motivation is causally and positively linked to relationship satisfaction in nonprofit blood donor settings.

Due to pervasiveness of perceived entity's judgment some comment could be given concerning the variability of the satisfaction outcome and cognitive efforts or consumer involvement in the consumption process. Contextual factors, such as social marketing, could change consumer expectations and processing motivation in the meaning of the importance of consumption outcomes to the consumer or cognitive efforts in deliberating these outcomes. However, if the process of service delivery and outcomes do not change respectively, satisfaction decreases. Therefore the nature of the link between variables of relationship satisfaction and donor motivation could not be predicted.

The literature has pointed out the positive relationship between customer satisfaction and customer loyalty (Anderson, 1994). Some authors have indicated mediating role of customer satisfaction in the effect of service quality on service loyalty (Caruana, 2002), however, there have been other contradictory findings highlighting the constraints that could impact positive satisfaction - loyalty relationship. Previous research has confirmed that factors of customer demographic characteristics - age (Lambert-Pandraud et al., 2005; Verhoef, Donkers, 2005), gender (Verhoef, Donkers, 2005) - are significant factors of customer loyalty, influencing the satisfaction - loyalty relationship. Older customers and female customers are likely exhibit higher levels of loyalty. These demographic characteristics are relevant in blood collection settings as well as in commercial settings. However, the reasoning how the factors of customer age and gender could influence the customer loyalty is based on the value exchange transaction evidences, such as customer purchasing involvement and brand loyalty, the impact of the demographic characteristics on the donor satisfaction - donor loyalty relationship is not obvious. Therefore, in this study we have not proposed explicit hypothesis for the donor satisfaction - donor loyalty path of the framework.

Effect of donor motivation on donor satisfaction and loyalty is variable due to the influence of common donorship attitudes prevailing in donor population, impact of social marketing programs, focused on promotion of donor commitment and deliberate donorship. Thus, we have predicted that effect of donor motivation on donor relationship satisfaction and loyalty change, following hypothesis proposed.

Hypothesis 4: The size and nature of the effects of donor motivation on donor relationship satisfaction, donor attitudinal loyalty and donor behavioural loyalty is variable. 


\section{Research Method}

Proposed model was tested by a large scale study. Sample data were collected from blood donors at a non-profit nationwide blood collection organization in two sessions of data collection - in December 2008 and December 2013. Two samples, examined for this study, were made of $N=448$ donors in 2008 and of $N=253$ donors in 2013. Missing answers were deleted listwise. After the screening of outliers, final sample size of $N=428$ for the first sample and $N=253$ for the second sample was used for the analysis. Table 1 presents the main characteristics of the samples.

Table 1. Sample characteristics

\begin{tabular}{|l|l|l|}
\hline \multicolumn{1}{|c|}{ Characteristics } & \multicolumn{1}{|c|}{ Sample 1 } & Sample 2 \\
\hline Donation & 195 & 156 \\
Remunerated & 250 & 95 \\
Non-remunerated & 3 & 2 \\
Missing response & & \\
Gender & 272 & 172 \\
Male & 173 & 80 \\
Female & 2 & 1 \\
Missing response & & \\
Relationship & 84 & 52 \\
First time donor & 24 & 14 \\
Sporadic (less than 1 time / year) donor & 21 & 21 \\
Sporadic (1 time / year) & 318 & 166 \\
Regular & 1 & \\
Missing response & \\
\hline
\end{tabular}

Literature did not provide relevant scale for the measure of donor motivation. Items of donor motivation were adopted from various authors (Sojka, Sojka, 2008; Bednall, Bove, 2011; Karacan et al., 2013; Pennings, 2005; Otto, Bolle, 2011). We measured donor motivation using 6 items: "Remuneration", "Possibility to get health consultation", "Possibility to help others", "Donation is useful for my health", "Donor is respected in society", "Influence from others".

A widely accepted loyalty items were adopted to measure donor loyalty (Sargeant, Woodliffe, 2007). 2 items for the attitudinal loyalty: "Willingness to recommend donate blood to family and friends", "Willingness to donate again" and 1 item for behavioral loyalty: "I donate the blood (first time, less than 1 time / year, 1 time / year, more than 1 time / year)". Behavioral loyalty measure captures actual donating behavior rather than perceived behavioral intentions.

Donor relationship satisfaction was measured using 4 item scale, donors were asked to evaluate the work of the contact personnel: "I am satisfied with the service of a receptionist", "I am satisfied with work of laboratory technician", "I am satisfied with service of a doctor", "I am satisfied with service of a nurse".

Structural equation modeling technique was used to test the hypothesized relationship between donor motivation, donor relationship satisfaction, attitudinal loyalty, behavioural loyalty constructs (Jöreskog, Sörbom, 1996). The hypotheses were tested by using two sample covariance matrixes separately. Exploratory factor analysis was used for the evaluation of the construct validity of a scale. Factor loadings are based on a principal axis factoring analysis with varimax rotation. Kaiser-Meyer-Olkin (KMO) and Bartlett's test of sphericity is used as measures of sampling adequacy. Two sets of SEM analyses were performed to test the models. The fit of each model was assessed with three indices - the chi-square / degree of freedom ratio, the goodness of fit index GFI, the root mean square error of approximation RMSEA. Cross-validation of two covariance matrixes provided results for the model stability. 


\section{Results}

Correlation analysis of the items in two samples suggested reasonable factorability - all items were significantly correlated with at least one other item. Measurement model was adjusted after reliability and validity checks. Measures of sampling adequacy were satisfactory, $\mathrm{KMO}=0.66$ and Bartlett's test of sphericity was significant $\left(\chi^{2}(78)=2148.21, p<0.05\right)$ for the first sample and $\mathrm{KMO}=0.79$ and Bartlett's test of sphericity was significant $\left(\chi^{2}(78)=1198.086, p<0.05\right)$ for the second sample. Extracted factors conformed to the constructs surveyed; all items met criteria of minimum factor loading of 0.4 and above (Appendix A, B). Slightly below the threshold loading value were found factor loadings for variables "Donor is respected in society" in first sample and "Possibility to get health consultation" in the second sample. Six factors explained more than $70 \%$ of the variance (result $73 \%$ for the first sample and $75 \%$ for the second sample). The factors of "Motivation based on contrary money-social values", "Motivation based on health benefit", "Prosocial motivation", "Relationship satisfaction", "Attitudinal loyalty", "Behavioural loyalty" suited the extracted factors. Also, it confirmed the findings of earlier studies.

The postulates about the structural model framework links were tested with SEM, including latent variables of donor motivation, attitudinal loyalty, behavioural loyalty and relationship satisfaction. The results of the proposed conceptual model (Figure 1) indicated a satisfactory fit to the data: $\chi^{2} / d f=23.92 / 15, p>0.05$, $\mathrm{GFI}=0.99$, RMSEA $=0.037$ for the first sample model and $\chi^{2} / d f=47.62 / 22, p<0.05$, GFI $=0.99$, RMSEA $=0.068$ for the second sample model.

An examination of parameter estimates revealed that it was probably that hypothesis 1 , hypothesis 2 and hypothesis 3 could be accepted with regard to the positive influence of donor motivation on attitudinal loyalty, behavioural loyalty and relationship satisfaction. Path coefficients were found meaningful for the causal direct relationship from donor motivation to attitudinal loyalty, behavioural loyalty, donor relationship satisfaction (Path coefficients are presented in Table 2).

Table 2. Path coefficients

\begin{tabular}{|l|l|l|}
\hline \multicolumn{1}{|c|}{ Relations } & \multicolumn{1}{c|}{$\begin{array}{c}\text { Path coefficient } \\
\text { estimate (Sample 1) }\end{array}$} & $\begin{array}{c}\text { Path coefficient } \\
\text { estimate (Sample 2) }\end{array}$ \\
\hline Donor motivation $\rightarrow$ Donor relationship satisfaction & 0.13 & 0.69 \\
\hline Donor motivation $\rightarrow$ Donor attitudinal loyalty & 0.15 & 1.42 \\
\hline Donor motivation $\rightarrow$ Donor behavioural loyalty & 0.53 & 1.21 \\
\hline Donor attitudinal loyalty $\rightarrow$ Donor behavioural loyalty & 0.26 & 0.57 \\
\hline Donor relationship satisfaction $\rightarrow$ Donor behavioural loyalty & -0.29 & 0.43 \\
\hline
\end{tabular}

The regression parameters estimated of the data, sampled twice from the same donor population, were comparable regarding the value amount. The power of motivation toward donor satisfaction and loyalty among the donors' of the surveyed population has increased during the period of five years. This effect could be explained by the positive moderating influence of the external factors on the donor perception of the motives to donate blood in relation to donor attitude and behaviour. Academic publications on the customer loyalty management subject have provided the arguments, that customer participation in the loyalty programs and loyalty behaviour has been driven by customer motives (Bolton et al., 2000). Following these research findings, we could provide some explication of the external factors, relevant for the blood donor population in the non-profit blood collection settings. Nationwide non-remunerated donorship promotion program, which promoted the voluntary and altruistic donorship motivation, has been implemented among the donor population during the period between the data collection sessions. Therefore, the social marketing means could be ascertained as a relevant external factor associated with this moderating effect.

The variability / volatility of the effects of donor motivation was tested using multi-sample analysis for tight and moderate replication of the parameter estimations in two data samples. Results of tight replication: $d f=51, \chi^{2}=375.969, p<0.05$, percentage contribution to $\chi^{2}=45.55$. Validation sample (second sample) was of the same influence as the calibration sample (first sample) since both samples have accounted about $50 \%$ 
of the overall model chi-square. Results of moderate replication: $d f=49, \chi^{2}=355.801, p<0.05$. Chi-square difference to compare the results of tight and moderate replication was equal to 20.078 with 2 degrees of freedom, which was not significant result per degree of freedom (probability value for a chi-square difference per degree of freedom is $p<0.05$ ). Therefore, model cross-validation showed the model stability, estimated model fitted well for two samples. We rejected hypothesis 4 concerning the variability of the effect of donor motivation on donor relationship satisfaction and loyalty.

The path coefficient for the link from donor attitudinal to behavioural loyalty was positive, showing that attitude toward behaviour was linked with actual behaviour, complying with the theory of planned behaviour. The path coefficient for the link from donor satisfaction to donor behavioural loyalty was found positive for the second data sample and negative for the first data sample. The positive relationship from satisfaction to donation behaviour was not supported by the data. This negative result was surprising, suggesting that lower donor relationship satisfaction could be related to higher frequency of donations. We posited that the reason for this result was much higher amount of paid (remunerated) donations in 2008 as compared to 2013. Donor motivation based on money value was the reason why unsatisfied donors may want to donate more frequently. This suggestion complied with the results of this study. Positive relationship from satisfaction to donor behaviour was found for the sample in 2013, when the number of paid donations decreased significantly.

\section{Discussion}

This study addressed a need to better describe donor motivation phenomena as the antecedent of donor satisfaction and loyalty behaviour. In conducting this study the notion of comparability of the relationship between the constructs in a various conditions of donorship environment was considered. This examination demonstrated that donor motivation could explain donor relationship satisfaction and loyalty behaviour within different external environment conditions.

The research contributed to the expectancy - value theory by providing the empirical evidences for motivation of individual's behaviour in non-profit context. This theory posited that individual's behaviour was driven by the valued outcomes of the behaviour. The consideration of behaviour alternatives with desired outcomes may be induced by the motivational forces or antecedents (Van Raaij, Wandwossen, 1978). The results of this study showed that antecedents of the behaviour were powerful to alter primary functional motivation for behaviour. The effect of Non-remunerated donorship promotion program and other external context forces were referred to as antecedents of the motives to donate. Donor motives to get benefit for the health during the donation procedure, to get remuneration, to fulfil the need for self-esteem by feeling respected in society, to fulfil the need for affiliation by helping other people were assessed in terms of their relative effect to composite motivation construct. The structure of the motivation construct varied during the five year period (2008-2013) - motive of self-esteem by feeling respected in society come up significant in 2013, the relative importance of the motive to get benefit for the health during the donation procedure decreased in 2013 as compared to 2008. Consequently, the alteration in motivation construct induced the effect on the links between motivation, satisfaction and donor behaviour. The path coefficients of motivation on donor behaviour and satisfaction relatively increased in 2013 as compared to 2008.

Non-profit context is relevant for the motivation process whereas the aesthetic - emotional and social motives prevail in non-profit exchanges. Value attributed to emotional and social outcome is based on intangible and non-dimensional criteria. The evaluation of the commercial product in terms of the product's ability to satisfy the particular need is mostly based on the definite characteristics. For example, motive based on the need for self-esteem could be the desired outcome addressed to the status product or sacrifice the blood to other people. The process of valuation will be more definitive for the first alternative choice.

Some limitations of this research could be related to the measurement of manifest indicators, which operationalize the constructs. Variables measuring attitudinal and behavioural loyalty are single - item constructs, and possibility that multi - item scales could provide different results still remains. The results also need to be considered in light of the limitation due to the common method bias. Self-report studies have been 
used frequently in the studies of consumer behaviour, however, the use of such type of report held to have some precaution concerning the validity of results. Observed correlations among the constructs of interest could be caused by the mono-method bias rather than the associations between the constructs itself (Spector, 1994). This problem of mono-method bias in the present research was reduced by cross-sectional design of questionnaire, which provided the insights of the peoples' perceptions of different phenomena of interest.

\section{Conclusions}

The results of the present study provided the evidence for the validity of the link between donor motivation, donor relationship satisfaction and donor loyalty behaviour. Perceived motives based on utility benefit and prosocial benefit drove the donor behaviour. Motive to get benefit for the health during the donation procedure (by possibility to get heath consultation and also benefit therefrom the donation procedure), and altruistic motive of self-esteem by possibility to help others were significant for the donor population surveyed. The structure of the motivation construct varied during the five year period (2008-2013) - relative importance of the motive of self-esteem by feeling respected in society come up significant in 2013 . The alteration in motivation construct induced the effect on the relationship satisfaction and loyalty behaviour - the path coefficients of motivation - behaviour model relatively increased in 2013 as compared to 2008 .

Presumably empirical findings of changes in donor motivation could be explainable as the outcome of the impact of external factors, relevant for the blood donor population in the non-profit context. Social marketing means could be ascertained as a relevant external factor associated with this efficient impact to donor motivation changes. Nationwide non-remunerated donorship promotion program, which promoted the voluntary and altruistic donorship motivation, has been implemented among the donor population during the period between the data collection sessions. The power of this promotion program is evidenced by increase in prominence of the motives, based on altruism and sacrifice, respectfulness in society.

Results of this research provided some evidence related to assumptions for efficient management of donor - blood collecting agency relationship. The main recommendations for the managers could be generalized identifying four tactical strategies: agencies should provide monitoring of donor motivation for the assessment of current motives for donation and ensure the knowledge about donor values and long term tendencies of donor preferences; agencies should provide social marketing designed to promote the ideas how blood collecting agencies satisfy donor needs; agencies should support the means of marketing for direct donor - agency communication and provide information about the donor's health test and ethically reasonable results of utilization of donated blood; agencies also should provide social marketing designed to promote the increase in overall level of expectancy that blood donation conform to the pro-social motives based on altruism and self-esteem.

\section{References}

Ajzen, I. (1991). The theory of planned behavior. Organizational Behavior and Human Decision Processes, Vol. 50 (2), p. 179-211.

Anderson, E. W. (1994). Cross-Category Variation in Customer Satisfaction and Retention. Marketing Letters, Vol. 5 (1), p. 19-30.

Anderson, E. W., Fornell, C., Lehmann, D. R. (1994). Customer Satisfaction, Market Share and Profitability: Finding From Sweden. Journal of Marketing, Vol. 58 (3), p. 53-66.

Anderson, E. W., Sullivan, M. W. (1993). The Antecedents and Consequences of Customer Satisfaction for Firms. Marketing Science, Vol. 12 (2), p. 125-143.

Arnett, D. B., German, S. D., Hunt, S. D. (2003). The Identity Salience Model of Relationship Marketing Success: The Case of Nonprofit Marketing. Journal of Marketing, Vol. 67 (2), p. 89-105.

Babin, B. J., Griffin, M., Babin, L. (1994). The Effect of Motivation to Process on Consumer's Satisfaction Reactions. Advances in Consumer Research, Vol. 21, p. 406-411.

Bednall, T. C., Bove, L. L. (2011). Donating blood: a meta-analytic review of self-reported motivators and deterrents. Transfusion Medicine Review, Vol. 25(4), p. 317-334. 
Bednall, T. C., Bove, L. L., Cheetham, A., Murray, A. L. (2013). A systematic review and meta-analysis of antecedents of blood donation behavior and intentions. Social Science Medicine, Vol. 96, p. 86-94.

Boenigk, S., Helmig, B. (2013). Why Do Donors Donate? Examining the Effects of Organizational Identification and Identity Salience on the Relationships among Satisfaction, Loyalty, and Donation Behavior. Journal of Service Research, Vol. 16 (4), p. 533-548.

Bolton, R. N., Kannan, P. K., Bramlett, M. D. (2000). Implications of Loyalty Program Membership and Service Experiences for Customer Retention and Value. Journal of the Academy of Marketing Science, Vol. 28 (1), p. 95-108.

Bryant, E. B., Cha, J. (1996). Crossing the Threshold. Marketing Research, Vol. 8 (4), p. 20-28.

Caruana, A. (2002). The effects of service quality and the mediating role of customer satisfaction. European Journal of Marketing, Vol. 36 (7/8), p. 811-828.

Dick, A. S., Basu K. (1994). Customer Loyalty: Toward an Integrated Conceptual Framework. Journal of the Academy of Marketing Science, Vol. 22 (2), p. 99-113.

Fornell, C., Johnson, M. D., Anderson, E. W., Cha, J., Bryant, B. E. (1996). The American Customer Satisfaction Index: Nature, Purpose, and Findings. Journal of Marketing, Vol. 60 (October), p. 7-18.

Gronholdt, L., Martensen A., Kristensen K. (2000). The relationship between customer satisfaction and loyalty: cross industry differences. Total Quality Management and Business Excellence, Vol. 11, p. 509-514.

Gupta, S., Zeithaml, V. (2006). Customer Metrics and Their Impact on Financial Performance. Marketing Science, Vol. 25 (6), p. 718-739.

Homburg, Ch., Giering, A. (2001). Personal Characteristics as Moderators of the Relationship between Customer Satisfaction and Loyalty. Psychology and Marketing, Vol. 18 (1), p. 43-66.

Jöreskog, K. G., Sörbom, D. (1996). LISREL 8: User's reference guide. Chicago, IL: Scientific Software International.

Karacan, E., Seval G. C., Aktan, Z., Ayli, M., Palabiyikoglu R. (2013). Blood donors and factors impacting the blood donation decision: Motives for donating blood in Turkish sample. Transfusion and Apheresis Science, Vol. 49 (3), p. $468-473$.

Lambert-Pandraud, R., Laurent, G., Lapersonne E. (2005). Repeat Purchasing of New Automobiles by Older Consumers: Empirical Evidence and Interpretations. Journal of Marketing, Vol. 69, p. 97-113.

Mittal, V., Kamakura, W. A. (2001). Satisfaction, Repurchase Intent, and Repurchase Behavior: Investigating the Moderating Effect of Customer Characteristics. Journal of Marketing Research, Vol. 38 (1), p. 131-142.

Oliver, R. L. (1999). Whence Consumer Loyalty. Journal of Marketing, Vol. 63 (Special Issue), p. 33-44.

Otto, P., Bolle, F. (2011). Multiple facets of altruism and their influence on blood donation. The Journal of SocioEconomics, Vol. 40, p. 558-563.

Pennings, G. (2005). Demanding pure motives for donation: the moral acceptability of blood donations by haemochromatosis patients. Journal of Med Ethics, Vol. 31, p. 69-72.

Sargeant, A., Woodliffe, L. (2007). Building Donor Loyalty: The Antecedents and Role of Commitment in the Context of Charity Giving. Journal of Nonprofit \& Public Sector Marketing, Vol. 18 (2), p. 47-68.

Seiders, K., Glenn B., Voss, G. B., Grewal, D., Godfrey, A. L. (2005). Do Satisfied Customers Buy More? Examining Moderating Influences in a Retailing Context. Journal of Marketing, Vol. 69 (October), p. 26-43.

Sheth, J. N. (1976). A psychological model of travel mode selection. Advances in consumer research, p. 425-430.

Sojka, B. N., Sojka, P. (2008). The blood donation experience: self reported motives and obstacles for donating blood. Vox Sanguinis, Vol. 94(1), p. 56-63.

Spector, P. E. (1994). Using Self-Report Questionnaires in OB Research: A Comment on the Use of a Controversial Method. Journal of Organizational Behavior, Vol. 15(5), p. 385-392.

Thaler, J., Helmig, B. (2013). Theoretical framework of social marketing effectiveness - Drawing the big picture on its functioning. Journal of Nonprofit and Public Sector Marketing, Vol. 25(3), p. 211-236.

Van Raaij, W. F., Wandwossen, K. (1978). Motivation-Need Theories and Consumer Behavior. NA - Advances in Consumer Research, Vol. 5 (eds. K. Hunt, A. Abor, MI) Association for Consumer Research, p. 590-595.

Venkatesh, S., Smith, A. K., Rangaswamy, A. (2003). Customer Satisfaction and Loyalty in Online and Offline Environments. International Journal of Research in Marketing, Vol. 20, p. 153-175.

Verhoef, P. C., Donkers, B. (2005). The Effect of Acquisition Channels on Customer Loyalty and Cross-Buying. Journal of Interactive Marketing, Vol. 19 (2), p. 31-43.

Yi, Y. (1991). A Critical Review of Consumer Satisfaction. Review of Marketing, 1990 (ed. V. A. Zeithmal). Chicago: American Marketing Association, p. 68-123.

Neatlygintinos kraujo donorystės propagavimo programa 2006-2015 m. Lietuvos Respublikos sveikatos apsaugos ministro 2006 m. lapkričio 28 d. įsakymas Nr. V-992. Valstybès žinios, 2006.12.07, Nr. 133, Publ. Nr. 5039. 


\title{
KRAUJO DONORYSTES I GYVENDINIMAS: MOTYVACIJOS POVEIKIS DONORŲ PASITENKINIMUI IR LOJALUMUI
}

\author{
JOLANTA ŽEMGULIENE்
}

Vilniaus universitetas (Lietuva)

\section{Santrauka}

Didejjantis gydymui naudojamų kraujo produktų poreikis ir kraujo donorystės ịstaigų pastangos sutelkti gydymo poreikių požiūriu pakankamą donorų skaičių skatina naujų donorystės veiklos būdų, grindžiamų socialinių paslaugų vartotojų elgsenos žiniomis, taikymą. Šiame straipsnyje nagrinėjamas socialinių paslaugų vartotojų - donorų - elgsenos modelis, galintis paaiškinti, kaip formuoti donorų lojalumą, atsižvelgiant ị motyvus ir suvokiamą vartotojo pasitenkinimą gauta paslauga. Tyrimo tikslas - ịvertinti donorų (socialinių paslaugų vartotojų) lojalios elgsenos socialinès rinkodaros poveikio aplinkai veiksnius, vartotojų (donorų) lojalumo, suvokiamo pasitenkinimo paslaugą, donorystès motyvacijos veiksnius, susiejus ị konceptualų modeli.

Tirtam modeliui analizuoti taikyti struktūrinių lygčių modeliavimo ir duomenų rinkimo (anketinè apklausa) metodai. Tiriamieji - nacionalinès kraujo donorystès įstaigos donorai. Siekiant ịvertinti donorų lojalumo ir ji lemiančių veiksnių pokyčius, donorų apklausa buvo atliekama du kartus per penkerių metų laikotarpį. Pirmoji atlikta 2008 m., antroji - 2013 m. Šiuo laikotarpiu šalyje buvo ịgyvendinama Neatlygintinos kraujo donorystès propagavimo programa 2006-2015 m.

Tyrimo rezultatai atskleidè, kad donorų motyvacija lemia donorų suvokiamą pasitenkinimą paslauga, taip pat donorų požiūrị ị donorystę ir lojalumą donorystės organizacijai. Nustatyti šie vyraujantys motyvai tapti donoru: duodant kraują, gereja donoro sveikata, donoro kompensacijos išmoka, nauda siejama su donoro savivertès augimu, asmens bendruomeniškumo ir pasiaukojimo elgsenos raiškos poreikiu. Donoro motyvacijos raiška, lyginant dviejų apklausų rezultatus, pakito - išryškejjo socialiniai motyvai. Donorų motyvacijos kitimas gali būti susijęs su socialinès rinkodaros priemonių poveikiu.

Atlikto tyrimo rezultatai pagrindžia donorų, kaip socialinių paslaugų vartotojų, lojalios organizacijai elgsenos socialinės rinkodaros poveikio aplinkoje veiksnius - suvokiamą pasitenkinimą paslauga, donorystės motyvaciją. Apibendrinus empirinius duomenis, atskleidžiamas socialinės rinkodaros priemonių veiksmingumas formuojant socialinių paslaugų vartotojo motyvus, lemiančius vartotojo lojalios organizacijai elgsenos kaitą.

PAGRINDINIAI ŽODŽIAI: donoro motyvacija, donoro suvokiamas pasitenkinimas, donoro lojalumas.

JEL KLASIFIKACIJA: M380.

\section{Acknowledgement}

Data collection for this research was supported by the leading donorship institution in Lithuania - National Blood Center. 
Appendix A

Rotated component loadings for the first sample items

Extraction method Principal Axis Factoring, $\mathrm{KMO}=0.66$

\begin{tabular}{|c|c|c|c|c|c|c|}
\hline Component & $\begin{array}{c}\text { Relationship } \\
\text { satisfaction }\end{array}$ & $\begin{array}{l}\text { Attitudinal } \\
\text { loyalty }\end{array}$ & $\begin{array}{l}\text { Motivation } \\
\text { based on } \\
\text { contrary } \\
\text { money-social } \\
\text { values }\end{array}$ & $\begin{array}{l}\text { Motivation } \\
\text { based on } \\
\text { health } \\
\text { benefit }\end{array}$ & $\begin{array}{l}\text { Behavioural } \\
\text { loyalty }\end{array}$ & $\begin{array}{l}\text { Prosocial } \\
\text { motivation }\end{array}$ \\
\hline \multicolumn{7}{|l|}{ Donor motivation } \\
\hline Remuneration & -0.062 & -0.034 & -0.445 & 0.278 & -0.270 & -0.260 \\
\hline $\begin{array}{l}\text { Possibility to get health } \\
\text { consultation }\end{array}$ & -0.065 & 0.003 & 0.064 & 0.577 & 0.031 & 0.058 \\
\hline Possibility to help others & 0.006 & 0.047 & 0.598 & 0.122 & -0.052 & -0.045 \\
\hline $\begin{array}{l}\text { Donation is useful for my } \\
\text { health }\end{array}$ & 0.141 & 0.002 & -0.034 & 0.280 & 0.343 & 0.031 \\
\hline $\begin{array}{l}\text { Donor is respected in } \\
\text { society }\end{array}$ & 0.084 & 0.018 & 0.067 & 0.117 & 0.098 & 0.362 \\
\hline \multicolumn{7}{|c|}{$\begin{array}{l}\text { Donor attitudinal loyalty } \\
\text { (Sargean, Woodliffe, } \\
\text { 2007) }\end{array}$} \\
\hline & & 0.982 & 0.051 & -0.009 & 0.055 & 0.014 \\
\hline $\begin{array}{l}\text { Willingness to donate } \\
\text { again } \\
\text { Donor relationship } \\
\text { satisfaction }\end{array}$ & 0.094 & 0.974 & 0.046 & 0.013 & 0.037 & 0.008 \\
\hline \multicolumn{6}{|l|}{ I am satisfied with the } & 0.085 \\
\hline $\begin{array}{l}\text { I am satisfied with work } \\
\text { of laboratory technician }\end{array}$ & 0.779 & 0.112 & 0.003 & 0.006 & -0.041 & 0.050 \\
\hline \multirow{3}{*}{$\begin{array}{l}\text { I am satisfied with work } \\
\text { of doctor } \\
\text { I am satisfied with work } \\
\text { of nurse } \\
\text { Donor behavioural } \\
\text { loyalty } \\
\text { I donate the blood (first } \\
\text { time, less than } 1 \text { time / } \\
\text { year, } 1 \text { time / year, more } \\
\text { frequently than } 1 \text { / year) }\end{array}$} & 0.793 & 0.046 & 0.025 & -0.011 & 0.021 & 0.041 \\
\hline & 0.778 & 0.035 & 0.091 & -0.069 & 0.060 & 0.077 \\
\hline & 0.088 & 0.042 & 0.020 & -0.014 & 0.464 & -0.057 \\
\hline Eigenvalues & 3.013 & 1.863 & 1.304 & 1.219 & 1.153 & 1.045 \\
\hline $\begin{array}{l}\text { Percentage of total } \\
\text { variance }\end{array}$ & 23.18 & 14.33 & 10.03 & 9.38 & 8.87 & 8.04 \\
\hline
\end{tabular}


Appendix B

Rotated component loadings for the second sample items

Extraction method Principal Axis Factoring, $\mathrm{KMO}=0.79$

\begin{tabular}{|c|c|c|c|c|c|c|}
\hline Component & $\begin{array}{l}\text { Relationship } \\
\text { satisfaction }\end{array}$ & $\begin{array}{l}\text { Motivation } \\
\text { based on } \\
\text { health } \\
\text { benefit }\end{array}$ & $\begin{array}{l}\text { Attitudinal } \\
\text { loyalty }\end{array}$ & $\begin{array}{l}\text { Prosocial } \\
\text { motivation }\end{array}$ & $\begin{array}{c}\text { Behavioural } \\
\text { loyalty }\end{array}$ & $\begin{array}{l}\text { Motivation } \\
\text { based on } \\
\text { contrary } \\
\text { money- } \\
\text { social } \\
\text { values }\end{array}$ \\
\hline \multicolumn{7}{|l|}{ Donor motivation } \\
\hline Remuneration & -0.040 & -0.301 & 0.034 & -0.032 & 0.191 & -0.490 \\
\hline $\begin{array}{l}\text { Possibility to get health } \\
\text { consultation }\end{array}$ & 0.049 & 0.339 & 0.007 & 0.144 & -0.117 & 0.042 \\
\hline Possibility to help others & 0.064 & -0.050 & 0.079 & 0.098 & 0.091 & 0.501 \\
\hline $\begin{array}{l}\text { Donation is useful for my } \\
\text { health }\end{array}$ & -0.087 & 0.580 & 0.146 & 0.076 & 0.295 & 0.022 \\
\hline $\begin{array}{l}\text { Donor is respected in } \\
\text { society }\end{array}$ & 0.157 & 0.310 & 0.040 & 0.682 & 0.251 & 0.031 \\
\hline Influence from others & -0.068 & 0.035 & -0.002 & 0.380 & -0.077 & 0.076 \\
\hline \multicolumn{7}{|l|}{$\begin{array}{l}\text { Donor attitudinal loyalty } \\
\text { (Sargean, Woodliffe, 2007) }\end{array}$} \\
\hline $\begin{array}{l}\text { Recommendation to family } \\
\text { and friends }\end{array}$ & 0.145 & 0.223 & 0.457 & 0.031 & -0.043 & 0.183 \\
\hline \multicolumn{7}{|l|}{ Donor relationship } \\
\hline $\begin{array}{l}\text { satisfaction } \\
\text { I am satisfied with the } \\
\text { service of receptionist }\end{array}$ & & & & & & \\
\hline \multirow{2}{*}{$\begin{array}{l}\text { I am satisfied with work of } \\
\text { laboratory technician } \\
\text { I am satisfied with work of } \\
\text { doctor }\end{array}$} & 0.881 & 0.055 & 0.187 & 0.000 & -0.026 & 0.027 \\
\hline & 0.943 & -0.012 & 0.086 & 0.017 & 0.035 & 0.028 \\
\hline $\begin{array}{l}\text { I am satisfied with work of } \\
\text { nurse }\end{array}$ & 0.855 & -0.030 & 0.150 & -0.018 & 0.124 & 0.048 \\
\hline \multirow{2}{*}{$\begin{array}{l}\text { Donor behavioural loyalty } \\
\text { I donate the blood (first } \\
\text { time, less than } 1 \text { time / year, } \\
1 \text { time / year, more than } 1 \text { / } \\
\text { year) }\end{array}$} & 0.898 & 0.052 & -0.069 & 0.020 & 0.103 & 0.106 \\
\hline & 0.176 & 0.009 & 0.088 & -0.004 & 0.598 & 0.000 \\
\hline Eigenvalues & 3.690 & 1.716 & 1.293 & 1.146 & 1.027 & 0.977 \\
\hline Percentage of total variance & 28.38 & 13.20 & 9.95 & 8.81 & 7.90 & 7.51 \\
\hline
\end{tabular}

